\title{
Experimental Study on Frost Resistance of High Titanium Heavy Slag Concrete
}

\author{
Song Zhong ${ }^{1,2 *}$, Wei Chen ${ }^{2}$, Wei Wang ${ }^{2}$, Linze $\mathrm{Li}^{1,2}$, Long Xie ${ }^{1,2}$ \\ (1. School of Architectural and Civil Engineering, Xihua University, Chengdu 610039, Sichuan, \\ China; \\ 2. Key Laboratory of comprehensive utilization of industrial solid waste in Sichuan Province, \\ Panzhihua University, Panzhihua 617000, Sichuan, China)
}

Keywords:frost resistance; high titanium heavy slag concrete; fly ash; ganister sand; slag Abstract: The experiment studies the frost resistance of high titanium heavy slag concrete by conducting 50 cycles of freezing and thawing on the high titanium heavy slag concrete test block with the standard slow freezing method. It researches the effects on frost resistance of high titanium heavy slag concrete under the following three conditions: different fly ash replaces the cement admixture; silica fume replaces $10 \%$ of cement; and steel slag replaces all fly ash. And then the experiment compares the frost resistance of high titanium heavy slag concrete with that of ordinary high titanium heavy slag concrete. Experimental study indicates that different mixture ratio of high titanium heavy slag concrete exerts certain influence on its frost resistance, mass loss and strength loss. The frost resistance of high titanium heavy slag concrete is in accordance with the requirements of < standards for test methods of long-term performance and durability of ordinary concrete > (GB/T 50082-2009).

\section{Introduction}

In Panxi area, there is a large amount of high titanium heavy slag sand and stone. Using them to prepare the special concrete has the following significance: can greatly reduce the cost; broaden the application areas of heavy high titanium slag; and improve the research system of high titanium heavy slag concrete. Making use of high titanium heavy slag as a raw material for preparing antifreezing concrete, not only can save natural resources, but also can improve the safety and durability of antifreezing concrete's structures. It has obvious social, economic and environmental benefits and is propitious to the sustainable development of urban construction in Panxi area ${ }^{[1]}$. The research achievements of high titanium heavy slag concrete in Panxi region are gradually maturing, and one of the hot issues is its frost resistance.This paper analyzes the frost resistance of the high titanium heavy slag concrete, thus providing a theoretical basis for the high titanium heavy slag concrete to make antifreezing concrete.

\section{Test on the Frost Resistance of High Titanium Heavy Slag Concrete}

\section{Raw Materials}

The experiment takes the high titanium heavy slag produced by Panzhihua Huanye Co., Ltd as the aggregate to prepare antifreezing concrete.

(1) High titanium heavy slag sand and fine stone

The performance indexes of high titanium heavy slag sand and high titanium heavy slag fine stone are shown in Table 1. 
Table 1. Performance indexes of high titanium heavy slag sand and high titanium heavy slag fine stone

\begin{tabular}{cccccc} 
Performance & $\begin{array}{c}\text { Manifest } \\
\text { density } \\
/\left(\mathrm{kg} / \mathrm{m}^{3}\right)\end{array}$ & $\begin{array}{c}\text { Bulk } \\
\text { density } \\
/\left(\mathrm{kg} / \mathrm{m}^{3}\right)\end{array}$ & $\begin{array}{c}\text { Fineness } \\
\text { modulus }\end{array}$ & $\begin{array}{c}\text { Maximum } \\
\text { particle diameter } \\
/(\mathrm{mm})\end{array}$ & $\begin{array}{c}\text { Crush } \\
\text { index } \\
/(\%)\end{array}$ \\
\hline $\begin{array}{c}\text { High titanium } \\
\text { heavy slag sand } \\
\begin{array}{c}\text { High titanium } \\
\text { heavy slag fine } \\
\text { stone }\end{array}\end{array}$ & 3130 & 1770 & 2.8 & 1 & 1 \\
\hline
\end{tabular}

(2) Cement and additives

Take the Panzhihua Ruifeng P.O42.5R cement. Its performance index is shown in Table 2.

Adopt the Panzhihua Jiyuan admixtures. Its water reduction rate is $17.6 \%$, and volume accounts for $1.64 \%$ of the total gel.

Table 2. The performance index of cement

\begin{tabular}{|c|c|c|c|c|c|c|c|}
\hline \multicolumn{2}{|c|}{$\begin{array}{l}\text { Flexural strength } \\
\text { /(Mpa) }\end{array}$} & \multicolumn{2}{|c|}{$\begin{array}{c}\text { Compressive strength } \\
/(\mathrm{Mpa})\end{array}$} & \multicolumn{2}{|c|}{ Coagulation time /(min) } & \multirow{2}{*}{$\begin{array}{c}\text { Water-pr } \\
\text { oportion } \\
/(\%)\end{array}$} & \multirow{2}{*}{ Stability } \\
\hline $3 d$ & $28 \mathrm{~d}$ & $3 d$ & $28 \mathrm{~d}$ & $\begin{array}{c}\text { Initial } \\
\text { Coagulation }\end{array}$ & $\begin{array}{c}\text { Final } \\
\text { Coagulation }\end{array}$ & & \\
\hline 4.6 & 6.9 & 26.1 & 49.5 & 67 & 240 & 29.6 & eligibility \\
\hline
\end{tabular}

(3) Fly ash, silica fume and steel slag

The performance indictors of fly ash, silica fume and steel slag are shown in Table 3.

Table 3. Performance indexes of fly ash, silica fume and steel slag

\begin{tabular}{ccccc}
$\begin{array}{c}\text { Performance } \\
\text { indexes }\end{array}$ & $\begin{array}{c}\text { Particle } \\
\text { diameter } \\
/(\mu \mathrm{m})\end{array}$ & $\begin{array}{c}\text { Specific } \\
\text { surface } \\
\text { area } /\left(\mathrm{m}^{2} / \mathrm{g}\right)\end{array}$ & $\begin{array}{c}\text { Water - } \\
\text { proportion } \\
/(\%)\end{array}$ & $\begin{array}{c}\text { Ignition } \\
\text { loss ratio } \\
/(\%)\end{array}$ \\
\hline $\begin{array}{c}\text { Froduct } \\
\text { name }\end{array}$ & $50 \sim 65$ & $0.8 \sim 1.2$ & 98.5 & 1.87 \\
Silica fume & $0.1 \sim 0.3$ & $20 \sim 28$ & 95.3 & 1.68 \\
Steel slag & $5 \sim 20$ & $0.4 \sim 0.8$ & 94.7 & 0.06 \\
\hline
\end{tabular}

\section{Mixture Ratio}

The mixture proportion of high titanium heavy slag antifreezing concrete is shown in Table 4.

Table 4. The mixture proportion of high titanium heavy slag antifreezing concrete (unit: $\mathrm{kg} / \mathrm{m}^{3}$ )

\begin{tabular}{|c|c|c|c|c|c|c|c|c|c|c|}
\hline Grade & number & $\begin{array}{c}\text { High } \\
\text { titanium } \\
\text { heavy } \\
\text { slag } \\
\text { sand/ } \\
\left(\mathrm{kg} / \mathrm{m}^{3}\right)\end{array}$ & $\begin{array}{c}\text { High } \\
\text { titanium } \\
\text { heavy } \\
\text { slag fine } \\
\text { stone/ } \\
\left(\mathrm{kg} / \mathrm{m}^{3}\right)\end{array}$ & $\begin{array}{c}\text { Cement } \\
42.5 \mathrm{R} \\
/\left(\mathrm{kg} / \mathrm{m}^{3}\right)\end{array}$ & $\begin{array}{c}\text { Fly ash } \\
/\left(\mathrm{kg} / \mathrm{m}^{3}\right)\end{array}$ & $\begin{array}{c}\text { Steel } \\
\text { slag } \\
/\left(\mathrm{kg} / \mathrm{m}^{3}\right)\end{array}$ & $\begin{array}{c}\text { Silica } \\
\text { fume } \\
/\left(\mathrm{kg} / \mathrm{m}^{3}\right)\end{array}$ & $\begin{array}{l}\text { Admixture } \\
/\left(\mathrm{kg} / \mathrm{m}^{3}\right)\end{array}$ & $\begin{array}{c}\text { water } \\
/\left(\mathrm{kg} / \mathrm{m}^{3}\right)\end{array}$ & $\begin{array}{c}\text { Volume } \\
\text { of fly } \\
\text { ash/(\%) }\end{array}$ \\
\hline \multirow{6}{*}{$\mathrm{C} 30$} & B1 & 940 & 890 & 330 & 120 & 0 & 0 & 7.5 & 260 & 26.7 \\
\hline & B2 & 940 & 890 & 350 & 100 & 0 & 0 & 7.5 & 260 & 22.2 \\
\hline & B3 & 940 & 890 & 370 & 80 & 0 & 0 & 7.5 & 260 & 17.8 \\
\hline & B4 & 940 & 890 & 450 & 0 & 0 & 0 & 7.5 & 260 & 0 \\
\hline & B21 & 940 & 890 & 315 & 100 & 0 & 35 & 9.0 & 260 & 22.2 \\
\hline & B22 & 940 & 890 & 350 & 0 & 100 & 0 & 7.5 & 260 & 0 \\
\hline
\end{tabular}

\section{Experimental Design}

In the test, $100 \mathrm{~mm} \times 100 \mathrm{~mm} \times 100 \mathrm{~mm}$ cube specimen based on the mixture ratio in each number in Table 4 are made. According to the proportion of each number, nine test blocks are produced and there are 54 test pieces in total. Test pieces in each number are divided into three groups with three in 
a group. Cube specimen in each number are separately put to compressive strength test for 7 days, compressive strength test for 28 days and compressive strength test after 50 times freeze-thaw circle. According to the requirements to the standard slow freezing method in " standards for test methods of long-term performance and durability of ordinary concrete " (GB / T 50082-2009) ${ }^{[2]}$, the temperature of the test chamber during.

freezing ranges from $(-20 \text { to }-18)^{\circ} \mathrm{C}$; during the melting, the temperature of the water soaking the concrete in the test chamber remains within $(18 \sim 20){ }^{\circ} \mathrm{C}$ range. After 50 cycles of freezing and thawing, test measuring the mass loss and strength loss is performed.

\section{Experimental Results and Analysis}

\section{Experimental Results}

As shown in Table 5 and Table 6, through experimental study on batch of high titanium heavy slag concrete, the following results are obtained: concrete slumps of different mixing proportions; compressive strength within 7days; compressive strength within 28days; compressive strength after 50 times freeze-thaw cycles; and mass loss and strength loss of concrete after freezing and thawing cycles.

Table 5. Experimental results of high titanium heavy slag concrete

\begin{tabular}{|c|c|c|c|c|c|c|}
\hline \multirow[b]{2}{*}{ Number } & \multicolumn{2}{|c|}{ Before freezing and thawing } & \multicolumn{2}{|c|}{$\begin{array}{c}\text { After } 50 \text { times freeze-thaw } \\
\text { cycles }\end{array}$} & \multirow{2}{*}{$\begin{array}{l}\text { Slump } \\
/(\mathrm{mm})\end{array}$} & \multirow{2}{*}{$\begin{array}{c}7 \text { days } \\
\text { compressive } \\
\text { strength } \\
/(\mathrm{Mpa})\end{array}$} \\
\hline & Mass/(kg) & $\begin{array}{c}28 \text { days } \\
\text { compressive } \\
\text { strength/(Mpa) }\end{array}$ & Mass/(kg) & $\begin{array}{l}\text { Compressive } \\
\text { strength/(Mpa) }\end{array}$ & & \\
\hline B1 & 2.492 & 49.5 & 2.482 & 47.1 & 175 & 33.2 \\
\hline $\mathrm{B} 2$ & 2.521 & 51.0 & 2.512 & 48.7 & 170 & 37.4 \\
\hline B3 & 2.510 & 52.4 & 2.501 & 49.7 & 166 & 36.7 \\
\hline B4 & 2.476 & 54.5 & 2.466 & 51.3 & 160 & 41.8 \\
\hline B21 & 2.550 & 55.2 & 2.545 & 53.2 & 177 & 43.1 \\
\hline B22 & 2.532 & 52.2 & 2.475 & 50.1 & 180 & 38.6 \\
\hline
\end{tabular}

Table 6. Frost resistance indexes of high titanium heavy slag concrete

\begin{tabular}{ccc}
\hline Number & Mass loss/(\%) & Strength loss/(\%) \\
\hline B1 & 0.402 & 4.85 \\
B2 & 0.357 & 4.51 \\
B3 & 0.379 & 5.15 \\
B4 & 0.404 & 5.87 \\
B21 & 0.196 & 3.62 \\
B22 & 0.225 & 4.02 \\
\hline
\end{tabular}

\section{Influence of Different Dosages of Fly Ash on the Frost Resistance of High Titanium}

\section{Heavy Slag Concrete with Total Amount of Powder Unchanged}

When the fly ash content is around $20 \%$, the strength loss and mass loss of high titanium heavy slag concrete after 50 times freeze-thaw cycles a relatively small. As increasing the dosage of fly ash, mild loss is modest, but more cement is saved, thus having better economic benefit. It shows that adding fly ash in high titanium heavy slag concrete can effectively improve the frost resistance of high titanium heavy slag concrete ${ }^{[3]}$.

\section{Influence of Silicon Powder on Frost Resistance of High Titanium Heavy Slag Concrete}

Silicon powder is a kind of very fine particles and mixing materials with high activity. Its main composition is amorphous $\mathrm{SiO}_{2}$. Because of its relatively high activity, when it is incorporated into concrete with superplasticizer, there is a chemical reaction between silica fume and $\mathrm{Ca}(\mathrm{OH})_{2}$ which produces hydrated calcium silicate gel. It fills the gap between the cement particles and improves the 
structure of interface system and the cohesive force, thereby increasing the density of concrete and reinforces its frost resistance ${ }^{[4]}$.

\section{Influence of Steel Slag on the Frost Resistance of High Titanium Heavy Slag Concrete}

Finely ground steel slag has good pozzolanic activity. Its main ingredient is $\mathrm{CaO}$, which can bring about the secondary reaction with $\mathrm{Ca}(\mathrm{OH})_{2}$ precipitated by cement hydration and generate CSH hydrates with low alkali. The heat releasing from hydration reaction is reduced, thereby improving the later strength and the durability of concrete. When finely grinding steel slag mixes with high titanium heavy slag powder, its activity becomes better. This is because mixing can have the effect of mutual activation, which in turn plays a better composite role, thus improving the mechanical properties of concrete. Incorporating steel slag powder into high titanium heavy slag concrete can effectively fill the large gap inside the high titanium heavy slag and reduce ice inflationary pressures as well as the extent of the damage effects. the steel slag can effectively improve the frost resistance of high titanium heavy slag concrete.

\section{Conclusion}

(1)When fly ash content is between $10 \%$ and $30 \%$, with the increase of fly ash, mild loss is modest, and it can also save more cement and have better economic returns. When at about $20 \%$ dosage of fly ash, the strength loss and mass loss of high titanium heavy slag concrete after 50 times of freeze-thaw cycles are smaller than that of the average high titanium heavy slag concrete. It shows that adding fly ash to high titanium heavy slag concrete can effectively improve the frost resistance of high titanium heavy slag concrete.

(2)When $10 \%$ cement is substituted with silica fume, before and after freezing and thawing, the mass loss of high titanium heavy slag concrete has decreased from $0.357 \%$ to $0.196 \%$, and strength loss has changed from $4.51 \%$ to $3.62 \%$. Compared with ordinary concrete, silica fume concrete has not only good mechanical properties, but also lower mass loss and strength loss after 50 cycles of freezing and thawing.Therefore, silicon powder is a kind of durable materials with good anti-freezing and thawing performance. When replacing $10 \%$ cement with silicon powder, the mass loss of high titanium heavy slag concrete is $0.196 \%$, and the strength loss is $3.62 \%$. Together, the mass loss and strength loss of high titanium heavy slag concrete are the least in the four cases: different dosages of fly ash replacing cement; silica powder displacing $10 \%$ cement; steel slag superseding all the fly ash and ordinary high titanium heavy slag concrete.

(3)When steel slag supersedes all the fly ash, the mass loss of high titanium heavy slag concrete changes from $0.357 \%$ before freeze-thaw to $0.225 \%$ after that. As for its strength loss, before and after freezing and thawing, it decreases from $4.51 \%$ to $4.02 \%$. Using steel salg instead of fly ash can improve the strength of the high titanium heavy slag concrete. At the same time, after 50 times of freeze-thaw cycle, the mass loss and strength loss of test blocks of high titanium heavy slag concrete mixed with steel slag are lower than that of common high titanium heavy slag concrete. So the slag can effectively improve the frost resistance of high titanium heavy slag concrete.

\section{References:}

[1] Huang SH, Chen W, Sun JK. Application of high titanium slag in concrete materials [J]. New Building Materials, 2006(11):71-73.[in Chinese].

[2] 《standards for test methods of long-term performance and durability of ordinary concrete》(GB/T 50082-2009) [S].2009.

[3] Liu AX. Performance and application of fly ash concrete[J].Concrete, 2001(12):6-8. [in Chinese]. [4] Yang P, Peng ZB. Discussion on the application of silicon powder in concrete [J]. Concrete, 2002(1):11-13. [in Chinese]. 